\title{
Simulation Study of Metal-semiconductor Back Contact p-c-Si/Al on Silicon Heterojunction Solar Cells
}

\author{
K. Bendjebbar ${ }^{1}$, D. Rached ${ }^{1}$, W.L. Rahal ${ }^{2,3, *}$, S. Bahlouli ${ }^{1}$ \\ ${ }^{1}$ Laboratoire de Physique des plasmas, Matériaux Conducteurs et leurs Applications, U.S.T.O.M.B. - \\ B.P. 1505, El M'naouar, Oran, Algérie \\ ${ }^{2}$ Laboratoire d'Analyse et d'Application des Rayonnements. U.S.T.O.M.B. - B.P. 1505, El M'naouar, \\ Oran, Algérie \\ ${ }^{3}$ Département de Physique, Faculté des Sciences Exactes et de l'Informatique, Université Abdelhamid \\ Ibn Badis de Mostaganem, Algérie
}

(Received 05 April 2020; revised manuscript received 15 October 2020; published online 25 October 2020)

\begin{abstract}
The silicon HIT (heterojunction with intrinsic thin layer) solar cell has great potential to improve photovoltaic efficiency and reduce costs because of the low temperature deposition technology of hydrogenated amorphous silicon a-Si:H combined with the high stable efficiency of crystalline silicon c-Si. To gain insight into the general functioning of the HIT solar cell, we have studied in this article the semiconductor-metal junction at the back contact of HIT $p$-type c-Si solar cell: (indium tin oxide (ITO)/hydrogenated $n$-doped amorphous silicon ( $n$-a-Si:H)/hydrogenated intrinsic polymorphous silicon (i-pm-Si:H)/p-doped crystalline silicon ( $p$-c-Si)/aluminum (Al)). Using computer modeling, we have found that unlike the junction on ITO/ $n$-a-Si:H on the front HIT solar cells which does not depend on the front contact barrier height $\phi_{b 0}$, an increase in the back contact barrier height $\phi_{b L}$ leads to an upward band bending in the valence band in this type of cell which eliminates the barrier for holes and makes more photogenerated holes able to pass from the active layer ( $p$-doped crystalline silicon $p$-c-Si) to the metal (aluminium). The increase in the electric field by changing the surface band bending at the junction $p$-c-Si/Al causes an increase in Voc which leads to an increase in the solar cell efficiency from $17.21 \%$ to $17.38 \%$. Choosing metal with high work function like palladium, chrome or ruthenium, could be the best choice as a back contact for this type of solar cell.
\end{abstract}

Keywords: HIT solar cells, Potential barrier, Current-voltage $J(V)$ characteristics, Crystalline silicon, Amorphous silicon.

DOI: $10.21272 /$ jnep.12(5).05022

\section{INTRODUCTION}

To make photovoltaic systems economically viable for large applications, high efficiency and inexpensive solar cells are required. The silicon Heterojunction with Intrinsic Thin layer (HIT) solar cells are an active field of research for photovoltaic applications due to the low cost and low temperature $\left(200^{\circ} \mathrm{C}\right)$ process of a-Si:H deposition coupled with the high efficiency and stability of c-Si [1]. An important progress on HIT has led to solar cells with efficiencies up to $26 \%$ [2]. To further improve the conversion efficiency of such solar cells, the main objective is to analyze and refine our understanding of the various factors limiting the performance of these cells. This can be best achieved with the help of a model capable of analyzing the transport properties in the devices applied to such disordered materials.

In this article, the device used is a HIT $p$-type c-Si solar cell: indium tin oxide (ITO)/hydrogenated $n$-doped amorphous silicon ( $p$-a-Si:H)/hydrogenated intrinsic polymorphous silicon (i-pm-Si:H)/p-doped crystalline silicon ( $p$-c-Si)/aluminum (Al) (Fig. 1).

The choice of work function at the interface between the active layer ( $p$-c-Si) and the metal (Al) is a crucial point for improving the efficiency of this type of solar cell. Indeed, Fig. 2 which represents the energy diagram at the $p$-c-Si/Al interface shows band bending in the valence
PACS numbers: 73.61.Jc, 71.20.Mq, 88.40.hj, 88.40.jj

and conduction bands (low work function of aluminum $E \phi_{A l} \approx 3.9 \mathrm{eV}$ compared to $p$-c-Si layer $E \phi_{p \text {-c-Si }} \approx 4.91 \mathrm{eV}$ ) $[3,4]$. This band bending will create a potential barrier at this interface and will impede the transmission of photogenerated holes towards the metal.

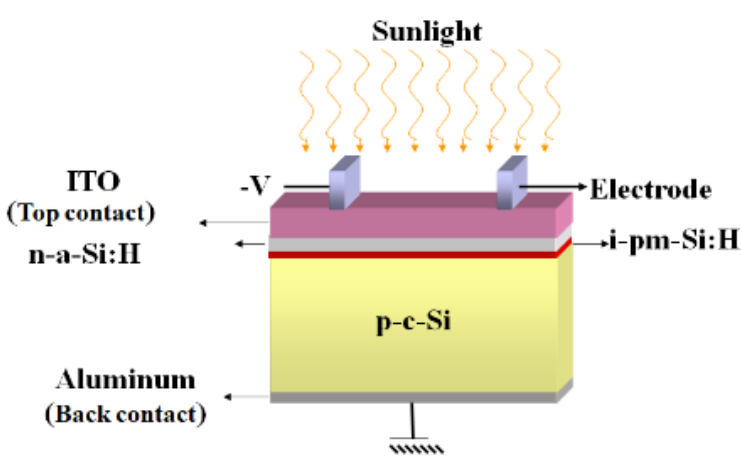

Fig. 1 - Schematic diagram of a HIT $p$-type c-Si (ITO/n-a-Si:H/ i-pm-Si:H/p-c-Si/Al) solar cell

In order to reduce the effect of this barrier between the active $p$-layer and the metal ( $p$-c-Si/Al), we have varied the surface band bending $E_{s b b}$ by changing the back contact barrier height $\left(\phi_{b L}\right)$. Experimentally we can change $\phi_{b L}$ by choosing different metals with different work functions [4].

\footnotetext{
*leila.rahal@univ-mosta.dz
} 


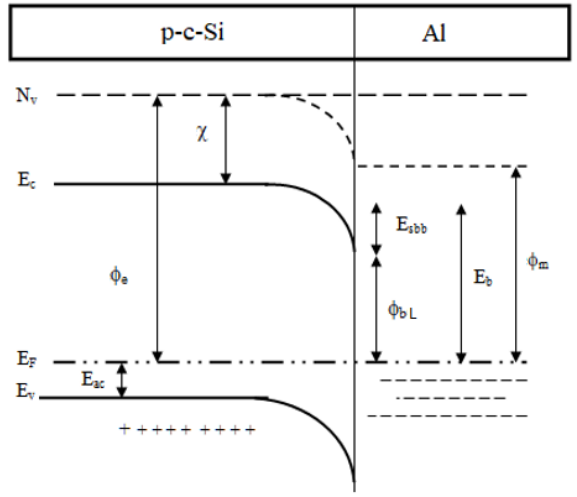

Fig. 2 - Contact $p$-c-Si/Al at thermodynamic equilibrium

Here in Fig. 2, $\chi$ is the electron affinity of the $p$-c-Si, $\phi_{m}$ is the work function of aluminum, $\phi_{e}$ is the work function of $p$-c-Si, $\phi_{b 0}$ is the back contact barrier height, $E_{s b b}$ is the surface band banding due to the barrier at $p$-c-Si/Al interface, $E_{a c}$ is the activation energy of $p$-c-Si.

\section{SIMULATION MODEL}

All calculations in this article have been done with Amorphous Semiconductor Device Modeling Program (ASDMP) [5-7], which was conceived to model amorphous silicon based devices and extended to HIT cells. ASDMP is a one-dimensional program. In the electrical part of the model, three coupled differential equations (the Poisson's equation and the two carrier continuity equations) are solved simultaneously under nonequilibrium steady-state conditions. The equations used are [8]:

$$
\begin{gathered}
\frac{d}{d x}\left(\varepsilon(x) \frac{d \psi(x)}{d x}\right)=\rho(x), \\
\frac{1}{q} \frac{d J_{n}(x)}{d x}+G_{o p t}(x)-R_{n e t}(x)=0 \\
\frac{1}{q} \frac{d J_{p}(x)}{d x}+G_{o p t}(x)-R_{n e t}(x)=0
\end{gathered}
$$

where $\varepsilon$ is the dielectric constant, $\psi(x)$ represents the potential energy of an electron at the vacuum level, $x$ is the position in the device, $\rho$ and $n$ are the valence-band hole density and the conduction band electron density, $q$ is the electronic charge, $R$ is the recombination rate.

The electrostatic field and the net charge density are given by the equations (2.4) and (2.5):

$$
\begin{gathered}
\rho(x)=q\left[p(x)-n(x)+p_{T}(x)-n_{T}(x)+N_{n e t}^{+}\right] \\
E=\frac{\partial \Psi(x)}{\partial x},
\end{gathered}
$$

where $\rho_{T}$ and $n_{T}$ are the trapped hole and electron population densities, respectively, $N_{\text {net }}$ is the net doping density, if any.

To simulate the dangling bond states, the gap-state distributions used combine the $U$-shaped model and two Gaussian distribution functions. The generation term in the continuity equations has been calculated using a semi-empirical model [9] that has been integrated into the modelling program. The calculation of the net charge density, discrete localized state model and the continuous localized state model are available in the literature [10].

\section{RESULTS AND DISCUSSION}

The schematic diagram of a $n$-HIT (ITO/n-a-Si:H/ i-pm-Si:H/p-c-Si/Al) solar cell used in the present work is illustrated in Fig. 1. In this cell, the parameters of each layer are summarized in Table 1 [11].

Table 1 - Input parameters extracted by modeling that characterize an $n$-HIT (ITO/n-a-Si:H/i-pm-Si:H/p-c-Si/Al) solar cell

\begin{tabular}{|l|l|l|l|}
\hline Parameters & $n$-a-Si:H & i-pm-Si:H & $p$-c-Si \\
\hline$d(\AA)$ & 80 & 30 & $300 \cdot 10^{4}$ \\
\hline$\chi(\mathrm{eV})$ & 4.00 & 3.95 & 4.22 \\
\hline$E_{\mu}(\mathrm{eV})$ & 1.80 & 1.96 & 1.12 \\
\hline$E_{\mathrm{ac}}(\mathrm{eV})$ & 0.21 & 0.92 & 0.06 \\
\hline$N_{D T O T}, N_{A T O T}\left(\mathrm{~cm}^{-3}\right)$ & $9.0 \cdot 10^{18}$ & $1.0 \cdot 10^{14}$ & $4.0 \cdot 10^{18}$ \\
\hline$E_{D}(\mathrm{eV})$ & 0.050 & 0.050 & 0.005 \\
\hline$E_{A}(\mathrm{eV})$ & 0.030 & 0.030 & 0.003 \\
\hline$G_{D 0}, G_{A 0}\left(\mathrm{~cm}^{-3} \mathrm{eV}^{-1}\right)$ & $4.0 \cdot 10^{21}$ & $4.0 \cdot 10^{21}$ & $4.0 \cdot 10^{20}$ \\
\hline$\mu_{n}\left(\mathrm{~cm}^{2} / \mathrm{V} \mathrm{s}\right)$ & 20 & 30 & 1000 \\
\hline$\mu_{\rho}\left(\mathrm{cm}^{2} / \mathrm{V} \mathrm{s}\right)$ & 4 & 12 & 450 \\
\hline$\phi_{b 0}(\mathrm{eV})$ & 0.12 & \\
\hline$\phi_{b L}(\mathrm{eV})$ & $1.06-1.22$ & \\
\hline
\end{tabular}

The front contact barrier height $\phi_{b 0}$ between ITO/ $n$-a-Si:H at $x=0$ is given by: $\phi_{b 0}=E_{\text {ac }}(n) \pm E_{s b b}$ and at the back contact, the barrier height $\phi_{b L}$ between $p$-c$\mathrm{Si} / \mathrm{Al}$ is given by $\phi_{b L}=E_{g}-E_{a c}(\rho) \pm E_{s b b}$ [8]. A previous study has shown that the performances of solar cells remain unchanged when the front contact barrier height $\phi_{b 0}$ increases (indium tin oxide (ITO)/hydrogenated $n$-doped amorphous silicon ( $p$-a-Si:H)) [11].

In Fig. 3, which represents the energy band diagram for $\phi_{b L}=1.06 \mathrm{eV}$ and $\phi_{b L}=1.22 \mathrm{eV}$, we notice a band bending in the valence and conduction bands between the junction $p$-type semiconductor and the metal ( $p$-c-Si/Al) when the back contact barrier height $\phi_{b L}$ increases. The upward band bending in the valence band will allow the photo-generated holes able to pass from the active $p$-layer ( $p$-c-Si) to the contact.

Fig. 4 represents the electric field under illumination for $\phi_{b L}=1.06 \mathrm{eV}$ and $\phi_{b L}=1.22 \mathrm{eV}$. We can notice in this graph an increase in the electric field when the value of $\phi_{b L}$ increases. Because of the absence of the barrier for holes between $p$-c-Si/Al (Fig. 3), the increase in this electric field allows more photogenerated holes able to pass from the $p$-c-Si to the aluminum.

Fig. 5 shows the short-circuit current density $J_{S C}$, open-circuit voltage $V_{O C}$, fill factor FF, and cell efficiency $\eta$ as functions of the back contact barrier height $\phi_{b L}$. The current-voltage $J(V)$ depends on the back contact barrier height. Indeed, we can see in Fig. 5 that the $V_{\mathrm{OC}}$ increases when $\phi_{b L}$ increases. The increase in the electric field causes an increase in $V_{O C}$ which leads to an increase in the solar cell efficiency from $17.21 \%$ to $17.38 \%$. No major change is observed in $J_{S C}$ and FF. 


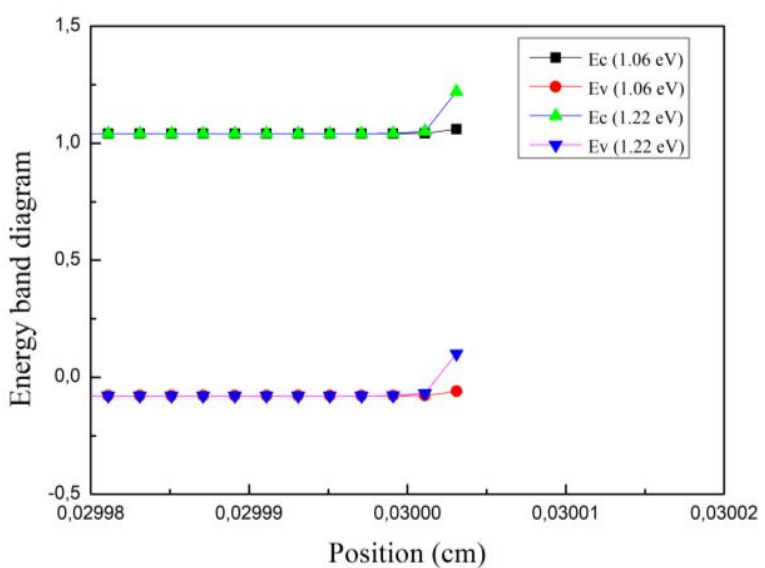

Fig. 3 - The schematic interface region band diagram under illumination for $\phi_{b L}=1.06 \mathrm{eV}$ and $\phi_{b L}=1.22 \mathrm{eV}$

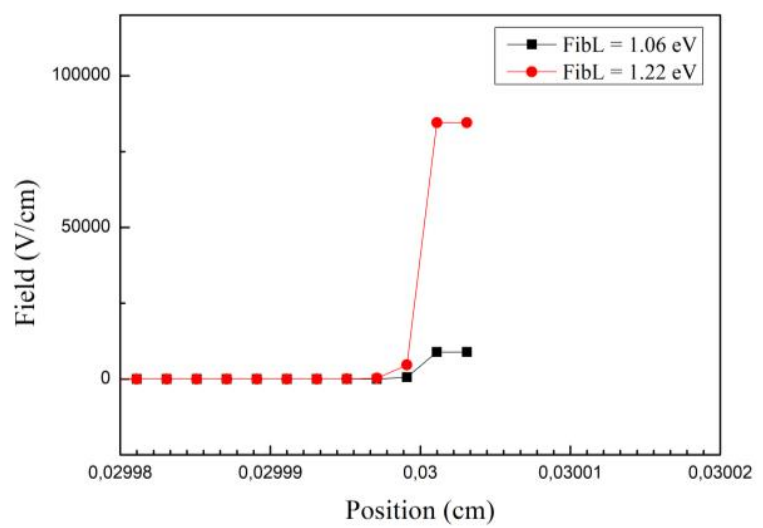

Fig. 4-Plots of the electric field under illumination for $\phi_{b L}=1.06 \mathrm{eV}$ and $\phi_{b L}=1.22 \mathrm{eV}$

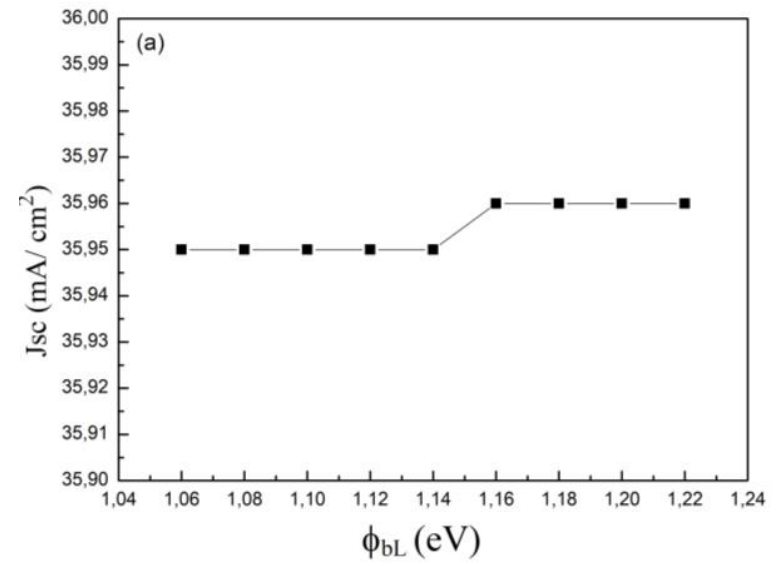

\section{CONCLUSIONS}

In summary, we have found that the cell performance depends on the back contact barrier height in $p$-doped crystalline silicon/aluminum heterojunction solar cells. Indeed, an increase in the front contact barrier height $\phi b 0$ does not give any change in $J(V)$ characteristics, but an increase in the back contact barrier height $\phi_{b L}$ creates a band bending in the valence band. This band bending eliminates the barrier for holes which will make
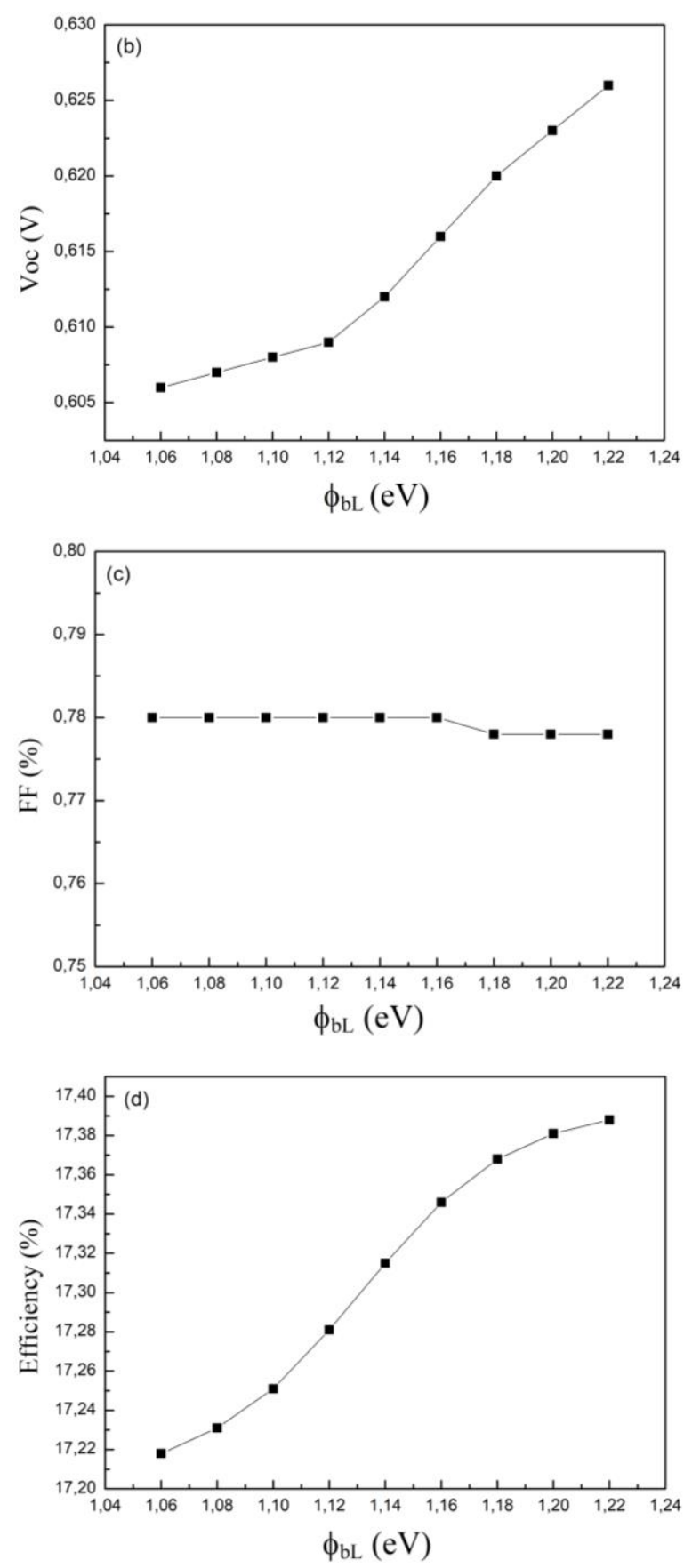

Fig. 5 - Plot of current-voltage $J(V)$ characteristics (short-circuit current density $J_{S C}(\mathrm{a})$, open-circuit voltage $V_{O C}(\mathrm{~b})$, fill factor FF (c), and cell efficiency $\eta(d))$ as functions of the back contact barrier height $\phi_{b L}$

more photogenerated holes able to pass from $p$-doped crystalline silicon to the metal. The increase in the electric field causes an increase in $V O C$ which leads to an increase in the solar cell output parameters. These results show that the choice of metal work function at the back contact of a HIT $p$-type c-Si solar cell is decisive to improve the efficiency of this type of cell. So, to improve $J(V)$ characteristics of this type of solar cells, it is preferable to use as back contact, metals with high work function like palladium, chrome or ruthenium. 


\section{REFERENCES}

1. M. Tanaka, S. Okamoto, S. Tsuge, and S. Kiyama, Proceedings of the Third World Conference on Photovoltaic Energy Conversion, 955 (Osaka: Japan: 2003).

2. M.A. Green, E.D. Dunlop, D.H. Levi, J. Hohl-Ebinger, M. Yoshita, A.W.Y. Ho-Baillie, Prog. Photovoltaics Res. Appl. 27, No 7, 565 (2019).

3. J. Hölzl, F.K. Schulte, Work Functions of Metals: Solid Surface Physics 85, 1 (G. Höhler Ed.) (Springer-Verlag: Berlin: 1979).

4. O. Tosoni, Université de Grenoble: Ph.D. Thesis (France: 2013).

5. M. Nath, P. Chatterjee, J. Damon-Lacoste, P. Roca i Cabarrocas, J. Appl. Phys. 103, 034506 (2008).
6. P. Chatterjee, M. Favre, F. Leblanc, J. Perrin, Mat. Res. Soc. Symp. Proc. 426, 593 (1996)

7. N. Palit, P. Chatterjee, Sol. Energy Mater. Sol. Cells 53, 235 (1998).

8. W.L. Rahal, D. Rached, J. Nano-Electron. Phys. 9 No 4, 04001 (2017).

9. F. Leblanc, J. Perrin, J. Schmitt, J. Appl. Phys. 75, 1074 (1994).

10. N. Palit, Energy Research, Indian Association for the Cultivation of Sciences: Ph.D. Thesis (India: 2000).

11. D. Rached, H. Madani Yssaad, W.L. Rahal, J. Nano- Electron. Phys. 10 No 5, 05012 (2018).

\title{
Імітаційне дослідження тилового контакту метал-напівпровідник p-c-Si/Al кремнієвих сонячних елементів з гетеропереходами
}

\author{
K. Bendjebbar ${ }^{1}$, D. Rached ${ }^{1}$, W.L. Rahal ${ }^{2,3}$, S. Bahlouli ${ }^{1}$ \\ ${ }^{1}$ Laboratoire de Physique des Plasmas, Matériaux Conducteurs et Leurs Applications, U.S.T.O.M.B. - \\ B.P. 1505, El M'naouar, Oran, Algérie \\ ${ }^{2}$ Laboratoire d'Analyse et d'Application des Rayonnements. U.S.T.O.M.B. - B.P. 1505, El M'naouar, \\ Oran, Algérie \\ ${ }^{3}$ Département de Physique, Faculté des Sciences Exactes et de l'Informatique, Université Abdelhamid \\ Ibn Badis de Mostaganem, Algérie
}

\begin{abstract}
Кремнієвий сонячний елемент з НІT (гетероперехід з власним тонким шаром) має великий потенціал для поліпшення фотоелектричної ефективності та зменшення витрат завдяки технології низькотемпературного осадження гідрогенізованого аморфного кремнію a-Si:H у поєднанні з високою стабільною ефективністю кристалічного кремнію c-Si. Щоб отримати чітке уявлення про загальне фрункціонування сонячного елемента з НIT, ми дослідили перехід напівпровідник-метал на тиловому контакті сонячного елемента c-Si $p$-типу з HIT: оксид індію та олова (ITO)/гідрогенізований $n$ легований аморфний кремній $(n$-a-Si:H)/гідрогенізований поліморфний кремній 3 власною провідністю (i-pm-Si:H)/p-легований кристалічний кремній (p-c-Si)/алюміній (Al). Використовуючи комп'ютерне моделювання, ми виявили, що на відміну від переходу ITO/n-a-Si:H на фронтальних сонячних елементах з НІТ, який не залежить від висоти бар'еру фронтального контакту $\phi b 0$, збільшення висоти бар'єру тилового контакту $\phi_{b}$ призводить до вигину вгору валентної смуги в цьому типі елементів, що усувае бар'єр для дірок і робить більше фотогенерованих дірок здатними переходити від активного шару ( $p$-легований кристалічний кремній $p$-c-Si) до металу (алюміній). Збільшення електричного поля за рахунок зміни вигину поверхневої смуги на переході $p$-c-Si/Al спричиняе збільшення $V_{O C}$, що призводить до збільшення ефективності сонячних елементів з $17,21 \%$ до $17,38 \%$. Вибір металу з високою роботою виходу, як паладій, хром або рутеній, може бути найкращим вибором як тилового контакту для цього типу сонячних елементів.
\end{abstract}

Ключові слова: Сонячні елементи з НІТ, Потенційний бар'єр, Вольт-амперні характеристики $J(V)$, Кристалічний кремній, Аморфний кремній. 